\title{
SOME EFFECTS OF INTELLECTUAL PROPERTY PROTECTION ON NATIONAL ECONOMIES: THEORETICAL AND ECONOMETRIC STUDY
}

\section{Tomáš Evan, Pavla Vozárová, llya Bolotov*}

\begin{abstract}
This paper aims to theoretically derive and afterwards econometrically assess the impact of intellectual property protection (IPP) on national economies. The authors' main hypothesis is that by creating a form of non-market protection, IPP limits free competition and has no positive effects on national economies and the world economy in general. The hypothesis is tested through estimation of relationship between charges for the use of intellectual property and 1) gross domestic product, 2) GDP growth, 3) unemployment, 4) exports of high-tech products, 5) FDI outflow, and 6) expenses on research and development in a panel dataset of 146 countries in years 2005-2014 based Arellano-Bond estimator for dynamic panel models. The data tells us that changes in these charges have not a significant impact on the studied indicators, which counts against claims of positive impact of IPP on economies and growth.
\end{abstract}

Keywords: intellectual property, economic theory, dynamic panel

JEL Classification: C22, C23, D40, O34, O40

\section{Introduction}

This paper aims to theoretically discuss and econometrically assess the impact of intellectual property protection (IPP) on the national economies. Intellectual property is defined by the World Intellectual Property Organization (WIPO, 2013) as "the legal rights which result from intellectual activity in the industrial, scientific, literary and artistic fields". IPP (WIPO, 2013) has a variety of forms, which are not limited to patents, they include industrial designs, trademarks, service marks, layout-designs of integrated circuits, commercial names and designations, as well as geographical indications, copyrights, protection against unfair competition and different forms of author rights. Today IPP resides upon many international agreements, the most recent of which are the TRIPS (Trade-Related Aspects of Intellectual Property Rights) agreement (1996) and the partly ratified ACTA (Anti-Counterfeiting Trade Agreement) agreement (2011-2012) ${ }^{1}$, as well as on numerous national legal norms.

\footnotetext{
* Tomáš Evan, Faculty of Information Technology, Czech Technical University in Prague; University of New York in Prague and Anglo-American University, Czech Republic (evantoma@fit.cvut.cz); Pavla Vozárová, Faculty of Information Technology, Czech Technical University in Prague, Czech Republic (pavla.vozarova@fit.cvut.cz);

Ilya Bolotov, University of Economics, Prague, Czech Republic (ilya.bolotov@vse.cz).

The authors want to thank Alexander P. Seither for valuable insights.

1 Not ratified by the European Parliament.
} 
The number of regulations has been increasing in time, especially since the $1970 \mathrm{~s}^{2}$, which has posed the question of optimum scale of IPP for economies.

The main hypothesis of this paper is that present-day IPP by creating a form of nonmarket protection already generates adverse effects and important opportunity costs, and does not positively affect gross domestic product (GDP) and GDP growth. After the presentation of theoretical arguments, the hypothesis is tested on a panel dataset of 149 countries and dependent territories and four subsets of the panel based on income for the years 2005-2014 with the help of dynamic panel data models. The paper is divided into four sections: historical overview and current state, theoretical discussion, methodology of tests and econometric methods and evaluation of results.

\section{History of IPP}

Historically there was a major opposition against any form of monopolization of ideas, namely patents, from the very beginning of existence of such regulation. Even before the first patent law was approved in Britain in 1815, there were Acts of Parliament giving patents on individual basis. Well known is the patent given to James Watt in 1768, which was spoken against with a great elocution, in the name of economic freedom and against the creation of unnecessary monopoly by the prominent conservative politician Edmond Burke. In this particular case, as argued by Boldrin and Levine (2008), inter alia the patent delayed industrial revolution for a decade or two.

However, it can be stated that despite opposition, after a series of treaties in the 19th century, stronger protection in form of the WIPO was established in 1967. Since 1995 trade-related aspects of property rights has become one of the pillars of the World Trade Organization (WTO). The "TRIPS" (1996) was the first agreement to create debate within the mainstream economics about the real impact of IPP on the world economy. Development in research has stimulated renewed interest in the impact that IPP predominantly has on investment and economic growth. The controversy surrounding the negotiation of the agreement at the GATT-WTO Uruguay Round stimulated research and publications, cf. next part of the paper. At the end of this process, the general understanding of the mainstream economists that more IPP means more research and development investment, more innovations, more exports, which leads to higher world economic growth, was broken.

The most recent important project, the ACTA treaty is planned to strengthen sanctions for violating intellectual property rights and to create another international institution besides the WIPO and the WTO. According to the WIPO, these measures have two goals: "One is to

2 The full list of IPP treaties includes the Paris Convention for the Protection of Industrial Property (1883), the Berne Convention for the Protection of Literary and Artistic Works (1886), the International Convention for the Protection of Performers, Producers of Phonograms and Broadcasting Organizations ("the Rome Convention", 1961), the Patent Cooperation Treaty (1970), the Locarno Agreement Establishing an International Classification for Industrial Designs (1971), the Strasbourg Agreement Concerning the International Patent Classification (1975), the Budapest Treaty on the International Recognition of the Deposit of Microorganisms for the Purposes of the Hague Agreement Concerning the International Deposit of Industrial Designs (1980), the Trademark Law Treaty (1994), the WIPO Copyright Treaty (1996), the WIPO-WTO Cooperation Treaty (1996), the Patent Law Treaty (2000), etc. 
give statutory expression to the moral and economic rights of creators in their creations and the rights of the public in access to those creations. The second is to promote, as a deliberate act of Government policy, creativity and the dissemination and application of its results and to encourage fair trading which would contribute to economic and social development". (WIPO, 2013). ACTA, according to its Preface, is also supposed to help sustain economic growth "across all industries and globally" and foster trade and sustainable development (MOFA, 2011). However, many economists, institutions and governments remained unconvinced that strengthening IPP can achieve these goals. This together with an obvious breach of several civil liberties is the reason why the ratification of the treaty is unlikely to be concluded soon.

Furthermore, the R\&D and innovations are mostly concentrated in a relatively small number of developed countries that are to a large extent headquarters of multinational corporations (MNCs), the importance of which as owners of IPP has increased in the recent decades (Lee and Mansfield, 1996). The role of the MNCs in the world economy and foreign direct investment (FDI), as well as the internationalization of IPP - transcending of their national character when licenses have to be purchased abroad - have to be taken into consideration when examining IPP, cf. Evan (2010) and Bolotov and Evan (2014).

\section{Theoretical Arguments Prevailing in Literature}

At the end of the last century, in most recent papers, the equivalence between innovation and IPP was quite straightforward. By some authors (Falvey, Foster and Greenaway, 2006) the intellectual property was considered to be a public good, therefore non-rivalrous and sometimes non-excludable, which was the reason for governmental or intergovernmental intervention. The incentive of IPP was considered necessary for inducing companies to invest in $R \& D$ and speeding up innovations and therefore economic growth. This view remains relatively intact when developed countries are discussed, as it is in those countries where heavy concentration of R\&D facilities is present and where most of the research is being done. For the world outside this handful of developed countries the situation is different. Falvey, Foster and Greenaway (2006) argue the impact of IPP protection on economic growth is likely to depend upon the country in question, in particular on its level of development and its ability to innovate and imitate. It is also argued that relationship between IPP and growth is a nonlinear one with countries with high incomes per capita likely to grow more rapidly, the stronger is the IPP. IPP is also reinforcing growth in the poorest countries presumably for the reason that they are unable to generate R\&D on their own and fully depend on MNCs' contribution to it. For the middle income countries the authors report no significant relationship. Indeed for the rest of the world economy, it is crucial how they are able to obtain technology; as countries rely on purchasing, spillovers through trade and FDI, imitation as well as piracy. According to Deardorff (1992), any strengthening of present-day IPP would be a profit transfer from developing countries to MNCs' headquarters in developed countries instead of strengthening domestic innovative capacity, the very reason why IPP was originally established.

The impact of IPP on economic growth for countries with different income has been studied extensively by researchers with varying methods, data samples and results. Sattar 
and Mahmood (2011) took a mix of 38 countries (11 from high-income countries, 16 from middle-income countries and 11 from low-income countries) over the period of 30 years (1975-2005). By utilizing Ginarte and Park Index of intellectual property rights they come up with results that there is a significant contribution of IPP to economic growth. According to them, the impact is more significant in high-income countries and as the country gets poorer the effect is less important. On a similar note, Kanwar and Evenson (2003) also using Ginarte and Park Index came up with a positive and significant impact of IPP on R\&D investment. They conclude that stronger protection can help to spur innovation and technological progress. Thompson and Rushing (1996) use a panel of 112 countries in a 15-year period (1970-1985). While they find positive coefficients between IPP and economic growth for high-income countries only, those are never significant. This is a long way from a paper somehow establishing the research on this topic back in 1984. Pakes and Griliches (1984) in their work "Patents and R\&D at the Firm Level: A First Look" did not come up with any concrete results but draw in researchers by claiming that something systematic and related to knowledge/producing activities is being measured by patents and that they are therefore, very much worthy of further study.

Recently, Iwaisako, Tanaka and Futagami (2011) found that improving patent protection may reduce the growth rate of output if the negative effect of patent protection on capital accumulation overwhelms the positive effect of innovation. According to them, if the relative productivity of $R \& D$ is sufficiently low, as it probably is in most middle and low-income countries, the negative effect overwhelms the positive one and strengthening IP rights impedes aggregate growth. The possibility that strengthening patent protection may impede economic growth is outlined in several other studies. The objection to patent protection known for two centuries is that a patent prevents other firms from utilizing the patented knowledge was studied by Michel and Nyssen (1998). They find out that extending patent length reduces knowledge spillovers and productivity of R\&D as well as limits the number of products. Horii and Iwaisako (2007) studied how stronger IPP potentially reduces economic growth. They claim that while IPP reduces imitation, it also reduces competing industries as businesses, which are able to do so, try to move to non-patented areas and create their own patent monopoly there. This finding explains the existence of MNCs" "shell" patents; in areas they are unable to proceed with R\&D activity at the time, to block future innovations by their competitors. Indeed, recent legal conflicts forced several state administrations to intellectual property reform. ${ }^{3}$

It can be said that in order to prove clear positive relationship between IPP and economic growth either via increased investment into R\&D or exports, researchers may consider dividing world economy into subsets of either open/closed economies or (1) subsets of low/ middle/high income countries (2), alternatively some authors choose supposedly random choice of countries for their data set (3).

3 By some estimates, shell patents or "patent trolls" now account for perhaps half of 4,000 patent cases a year in the USA, the US Administration announced some of its measures on June 4th, 2013. These measures are opposed predominantly by MNCs on the ground that buying and enforcing patents creates important market in invention that maximizes its financial rewards and thus encourages it. 


\section{Methodology for Tests Applied in This Paper}

In this paper the authors use a different, theoretical and econometric approach than the above-mentioned works.

\section{Proxy variable for IPP}

The authors argue based on Dunning's concept of the so-called "net ownership" (Dunning, 1998) that MNCs are ultimately the major benefactors of IPP. In the Dunning concept, it is possible to roughly equal the net ownership advantage with intellectual property possessed by MNCs, which is to be protected by recent treaties. Intellectual property is internal for the MNCs and easily used in various countries. This advantage depends on it being guaranteed by governments of host countries and intergovernmental agreements such as TRIPS and ACTA. The length of patent, the conditions of trademark registration or license are forms of support available to MNCs if agreed internationally and with host governments. The net ownership therefore plays a crucial role in the level of foreign direct investment and overall sustainability of doing business within several countries. Availability of intellectual property monopoly as provided by governments is crucial for MNCs which would ceteris paribus incur an important increase in costs and therefore in prices of production (Evan, 2010; Bolotov and Evan, 2014). Therefore an important symbiosis takes place: governments provide support to MNCs in form of financial subsidies (in form of investment incentive schemes), as well as increased monopoly power through international negotiations increasing IPP of MNCs as their crucial asset creating a market failure. MNCs are in turn redirecting their FDI from locations where the return of investment would be the greatest back to developed countries as the subsidies plus the increase of monopoly power over their intellectual property resources offset their loss of profits from otherwise suboptimal investment location. Considering the importance of link between present-day IPP and the activity of MNCs, as well as the above discussed geographical asymmetry of IPP, total (received and paid) charges for the use of intellectual property are therefore deployed as the main proxy for IPP. ${ }^{4}$

\section{Relationships between IPP and economic growth}

It is possible to assess the relationship between IPP (total charges for the use of intellectual property) ${ }^{5}$ and economic growth with the help of four variables: 1) GDP as a whole, 2) GDP growth, 3) unemployment, 4) FDI outflow, 5) expenditure on R\&D and 6) high-tech exports. Our main research question is of course focussing on the main macroeconomic indicators of countries' performance - GDP and GDP growth. If the purpose of IPP is to promote economic growth, then they should have a positive effect on GDP and its growth rate, which

$4 \quad$ MNCs, as well as local companies, in countries with functioning IPP either receive or pay non-zero charges for the use of intellectual property. Logically, the value of total charges for a country must be positively correlated with the degree of its IPP.

5 We measure payments (charges for the use of intellectual property, payments (BoP, current US\$)) going to MNCs and to other holders of IPP paid for use of their property by various firms in each observed country. These countries include the countries where the MNCs headquarters are situated. 
could be argued from a number of orthodox economic theories, such as the Keynesian multiplication-acceleration effect of growth in investment, as presented by Samuelson (1948), Samuelson and Nordhaus (2009) and others, or the new classical concept of increases in total factor productivity (TFP), as presented by Kydland and Sollow (1956), Swan (1956), Prescott (1982) and Long and Plosser (1983) and laterworks. ${ }^{6}$ Increasing economic performance of a country could be accompanied by decrease of unemployment, as showed by the Okun's law, Okun (1962); hence, IPP should have a negative impact on this variable. On the other hand, one could argue that intellectual property is largely involved only in the technologically advanced sectors of the economy. The more technologically advanced firms typically engage in trade and FDI, and so we check also whether IPP has some positive effect on FDI outflow from the country and its high-tech exports. And finally, even if we believe that accumulation of technological advantages is not imminent and that firms used to receive IPP charges to finance research and development that would only later bring the above mentioned advantages, then IPP charges should at least positively affect the R\&D expenditures.

To make our point clearer, we summarize hypotheses tested in Table 1:

Table 1 | Hypotheses

\begin{tabular}{|l|l|c|}
\hline Variable & \multicolumn{1}{|c|}{ Hypothesis } & Sign of effect \\
\hline GDP growth & IPP contributes to economic growth of a country & + \\
\hline GDP & IPP increases production in a country & + \\
\hline Unemployment & $\begin{array}{l}\text { Economic performance enhanced by IPP decreases } \\
\text { unemployment }\end{array}$ & + \\
\hline High-tech exports & $\begin{array}{l}\text { IPP increases production and hence also exports by } \\
\text { high-tech sectors }\end{array}$ & + \\
\hline FDI outflow & $\begin{array}{l}\text { IPP increases production of technologically advanced } \\
\text { firms that consecutively engage in FDI }\end{array}$ & + \\
\hline R\&D expenditure & $\begin{array}{l}\text { IPP is a source of financing for research and } \\
\text { development }\end{array}$ \\
\hline
\end{tabular}

\section{Data}

Altogether, we retrieved from the World Bank database information about 144 countries from all over the world, for which we observe the following characteristics:

- IPP charges

- GDP

- High-tech exports

- FDI outflow

- Unemployment

- R\&D expenditure

- Inflation
Charges for the use of intellectual property, payments (BoP, current US\$) GDP, PPP (constant 2011 international \$)

High-technology exports (\% of manufactured exports)

Foreign direct investment, net outflows (\% of GDP)

Unemployment, total (\% of total labour force)

Research and development expenditure (\% of GDP)

Inflation, GDP deflator (annual \%)

6 These theories suggest that an increase in IPP creates ceteris paribus a tendency (in the sense of John Stuart Mill's philosophy) for the growth in investment / TFP and subsequently in GDP. The effect, however, depends on the correspondence of the ceteris paribus assumption to the reality, i.e. to the existence and strength of numerous disturbing forces, which is an underlying idea of our study. 
Using the variable GDP, we constructed also the indicator of GDP growth.

Since the IPP charges are recorded in the database starting at the 2005 earliest and latest available record is for year 2014, we limited our data only to cover this time span. The list of countries covered in our dataset and descriptive statistics of used variables can be found in the Appendix. We can see there that the overall data coverage in our sample is relatively good, except for $\mathrm{R} \& \mathrm{D}$ expenditure, which is available only for approximatively half of the countries in given years.

We have thus constructed an unbalanced panel of $n=146$ countries and $T=10$ years. Since the time dimension of our panel is relatively short, we do not have to check for time series stationarity. Moreover, we planned from the beginning to use panel data models based on fixed effects or differencing, which would solve any problem related to first order integration of our time series.

Our research question is whether the charges for the use of intellectual property can in any way influence main indicators of the economy performance, such as GDP level, GDP growth, FDI outflow, high-tech exports, unemployment, or R\&D expenditure. To analyse this, we provide a set of panel data models, each in the form

$$
X_{i t}=\beta_{0}+\beta_{1} \text { IPP } \text { charges }_{t}+\beta_{2} X_{i t-1}+\beta_{3} \text { inflation }_{i t}+\alpha_{i}+\gamma_{t}+\varepsilon_{i t}
$$

where $X$ denotes one of the analysed indicators, $i$ represents the country, $t$ is the year index, $\alpha_{i}$ is the country-specific fixed effect, $\gamma_{t}$ is the year-specific fixed effect and $\varepsilon_{i t}$ is the idiosyncratic error term. We always include a lag of the variable $X$ since we expect that all studied indicators are prone to display an autoregressive pattern. Further, since IPP charges are provided in current prices, we also always include inflation in the equation to control for possible changes in price levels.

The decision of including the lagged explanatory variable in our model has one important consequence for the choice of method that we use for estimation. This lagged explanatory variable causes the FE estimator to be biased, as explained in Arellano and Bond (1991). The within transformation used by the FE estimator helps us to get rid of the fixed effect $\alpha_{i}$, but it adds in the equation the average of the idiosyncratic term $\overline{\varepsilon_{i}}$, which contains among other $\varepsilon_{i t-1}$, correlated with the lag of the explanatory variable and causing the bias. As $T$ tends to infinity, this bias decreases and the FE estimator is consistent, but in our sample with a maximum of 10 observations over time, the bias could be still quite significant.

For this reason, we decided to use as our basic method the Arellano-Bond estimator for dynamic panel models, which was proposed to solve exactly this issue. To control for possible heteroskedasticity, we use the version of the estimator with robust standard errors. 


\section{Results}

\subsection{All countries}

Results of our estimation performed over all countries in our sample are presented in Table 2:

Table 2 | Results of Regression with Current IPP Charges

\begin{tabular}{|c|c|c|c|c|c|c|}
\hline \multicolumn{7}{|c|}{ Explanatory variable } \\
\hline & $\begin{array}{l}\text { GDP } \\
\text { growth }\end{array}$ & $\begin{array}{l}\text { GDP } \\
(\log )\end{array}$ & $\begin{array}{l}\text { High-tech } \\
\text { exports }\end{array}$ & $\begin{array}{l}\text { FDI } \\
\text { outflow }\end{array}$ & $\begin{array}{l}\text { Unemploy- } \\
\text { ment }\end{array}$ & $\begin{array}{c}R \& D \\
\text { expenditure }\end{array}$ \\
\hline IPP charges (log) & $\begin{array}{c}0.0029 \\
(0.0035)\end{array}$ & $\begin{array}{l}0.0056^{* *} \\
(0.0026)\end{array}$ & $\begin{array}{c}0.2460 \\
(0.5353)\end{array}$ & $\begin{array}{c}5.2695 \\
(3.4236)\end{array}$ & $\begin{array}{c}0.0998 \\
(0.0962)\end{array}$ & $\begin{array}{l}-0.0077 \\
(0.0092)\end{array}$ \\
\hline Inflation & $\begin{array}{l}-0.0005^{* *} \\
(0.0002)\end{array}$ & $\begin{array}{l}-0.0003^{*} \\
(0.0002)\end{array}$ & $\begin{array}{c}-0.0402^{*} \\
(0.0211)\end{array}$ & $\begin{array}{l}-0.0409 \\
(0.0798)\end{array}$ & $\begin{array}{c}0.0025 \\
(0.0057)\end{array}$ & $\begin{array}{l}-0.0010 \\
(0.0007)\end{array}$ \\
\hline $\begin{array}{l}\text { Lag of GDP } \\
\text { growth }\end{array}$ & $\begin{array}{l}0.2398 * * * \\
(0.0827)\end{array}$ & $\begin{array}{l}- \\
-\end{array}$ & $\begin{array}{l}- \\
-\end{array}$ & $\begin{array}{l}- \\
-\end{array}$ & $\begin{array}{l}- \\
-\end{array}$ & $\begin{array}{l}- \\
-\end{array}$ \\
\hline Lag of GDP (log) & - & $\begin{array}{l}0.7785^{* * *} \\
(0.0532)\end{array}$ & - & - & - & - \\
\hline $\begin{array}{l}\text { Lag of high-tech } \\
\text { exports }\end{array}$ & $\begin{array}{l}- \\
-\end{array}$ & $\begin{array}{l}- \\
-\end{array}$ & $\begin{array}{l}0.4340^{* * *} \\
(0.1393)\end{array}$ & - & $\begin{array}{l}- \\
-\end{array}$ & $\begin{array}{l}- \\
-\end{array}$ \\
\hline Lag of FDI outflow & $\begin{array}{l}- \\
-\end{array}$ & $\begin{array}{l}- \\
-\end{array}$ & $\begin{array}{l}- \\
-\end{array}$ & $\begin{array}{l}-0.0187 \\
(0.1201)\end{array}$ & $\begin{array}{l}- \\
-\end{array}$ & $\begin{array}{l}- \\
-\end{array}$ \\
\hline $\begin{array}{l}\text { Lag of } \\
\text { unemployment }\end{array}$ & $\begin{array}{l}- \\
-\end{array}$ & $\begin{array}{l}- \\
-\end{array}$ & $\begin{array}{l}- \\
-\end{array}$ & $\begin{array}{l}- \\
-\end{array}$ & $\begin{array}{l}0.5983^{* * *} \\
(0.0461)\end{array}$ & $\begin{array}{l}- \\
-\end{array}$ \\
\hline $\begin{array}{l}\text { Lag of } R \& D \\
\text { expenditure }\end{array}$ & - & - & $\begin{array}{l}- \\
-\end{array}$ & $\begin{array}{l}- \\
-\end{array}$ & $\begin{array}{l}- \\
-\end{array}$ & $\begin{array}{l}0.4303^{* * *} \\
(0.1440)\end{array}$ \\
\hline Year effects & Yes & Yes & Yes & Yes & Yes & Yes \\
\hline $\begin{array}{l}\text { Number } \\
\text { of observations }\end{array}$ & 879 & 1011 & 757 & 837 & 949 & 445 \\
\hline
\end{tabular}

Note: Robust standard errors are in parentheses. ${ }^{* * *} p=0.01,{ }^{* *} p=0.05,{ }^{*} p=0.10$.

Source: Authors' own computations

Our results allow us to make several conclusions. First, all studied variables except for FDI outflow indeed display an autoregressive pattern. Second, the inflation is significant only for GDP growth, GDP and high-tech exports. Third and the most importantly, IPP charges have no significant effect on any of the indicators, except for GDP, for which we find a statistically significant (at $95 \%$ confidence level) but economically almost insignificant impact: 1 percent increase in IPP charges seems to imply a 0.0056 percent increase in GDP.

The weak but positive effect of IPP charges on GDP gets revised when we check the dynamic impact of IPP charges on our indicators. Assuming the effect does not need to be instantaneous, we modify our model by including one-year lag of IPP charges instead of the current level of these charges:

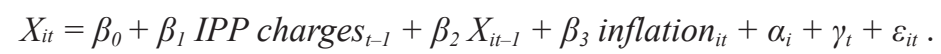


The results of this regression (again estimated using the Arellano-Bond estimator with robust standard errors) are presented in Table 3.

All coefficients remain almost the same, but the coefficient related to IPP charges changes dramatically when this variable is lagged. For the indicators of FDI outflow, hightech exports and unemployment, it remains insignificant (standard errors are too large indicating that there is probably not enough variation in our data), even though it becomes smaller or even negative in all cases.

At the same time, the coefficient is highly significant (at 99\% confidence level) and clearly negative for GDP growth, even though the impact is economically not important - 1 percent increase in IPP charges implies a decrease of GDP growth by 0.0071 percentage points. The impact on GDP is statistically weaker and still economically not very important - 1 percent increase in IPP charges implies 0.0026 percent decrease of GDP.

The last indicator that should be discussed is R\&D expenditure. Lagged IPP charges seem to have significantly positive effect on these expenditures. The increase of IPP charges in the previous year by 1 percent leads to increase of $\mathrm{R} \& \mathrm{D}$ expenditure as percentage of GDP by 0.0001 percentage point.

Table 3 | Results of Regression with Lagged IPP Charges

\begin{tabular}{|c|c|c|c|c|c|c|}
\hline \multicolumn{7}{|c|}{ Explanatory variable } \\
\hline & $\begin{array}{c}\text { GDP } \\
\text { growth }\end{array}$ & $\begin{array}{l}\text { GDP } \\
(\log )\end{array}$ & $\begin{array}{l}\text { High-tech } \\
\text { exports }\end{array}$ & $\begin{array}{c}\text { FDI } \\
\text { outflow }\end{array}$ & $\begin{array}{l}\text { Unemploy- } \\
\text { ment }\end{array}$ & $\begin{array}{c}R \& D \\
\text { expenditure }\end{array}$ \\
\hline $\begin{array}{l}\text { Lag of IPP } \\
\text { charges (log) }\end{array}$ & $\begin{array}{c}-0.0071 * * * \\
(0.0025)\end{array}$ & $\begin{array}{c}-0.0026^{*} \\
(0.0014)\end{array}$ & $\begin{array}{l}-0.4452 \\
(0.6539)\end{array}$ & $\begin{array}{c}0.2171 \\
(0.7802)\end{array}$ & $\begin{array}{l}-0.0138 \\
(0.0963)\end{array}$ & $\begin{array}{l}0.0121^{* *} \\
(0.0053)\end{array}$ \\
\hline Inflation & $\begin{array}{c}-0.0005^{* *} \\
(0.0002)\end{array}$ & $\begin{array}{c}-0.0004^{* *} \\
(0.0001)\end{array}$ & $\begin{array}{c}-0.0343^{*} \\
(0.0198)\end{array}$ & $\begin{array}{l}-0.0441 \\
(0.0728)\end{array}$ & $\begin{array}{l}-0.0010 \\
(0.0046)\end{array}$ & $\begin{array}{l}-0.0013^{*} \\
(0.0007)\end{array}$ \\
\hline $\begin{array}{l}\text { Lag of GDP } \\
\text { growth }\end{array}$ & $\begin{array}{l}0.2608^{* * *} \\
(0.0722)\end{array}$ & - & - & - & - & - \\
\hline Lag of GDP (log) & - & $\begin{array}{l}0.7509 * * * \\
(0.0226)\end{array}$ & - & - & - & - \\
\hline $\begin{array}{l}\text { Lag of high-tech } \\
\text { exports }\end{array}$ & - & - & $\begin{array}{l}0.4660 * * * \\
(0.1387) \\
\end{array}$ & - & - & - \\
\hline $\begin{array}{l}\text { Lag of FDI } \\
\text { outflow }\end{array}$ & $\begin{array}{l}- \\
-\end{array}$ & $\begin{array}{l}- \\
-\end{array}$ & $\begin{array}{l}- \\
-\end{array}$ & $\begin{array}{r}-0.0095 \\
(0.1209)\end{array}$ & $\begin{array}{l}- \\
-\end{array}$ & $\begin{array}{l}- \\
-\end{array}$ \\
\hline $\begin{array}{l}\text { Lag of } \\
\text { unemployment }\end{array}$ & - & - & - & - & $\begin{array}{l}0.5258 * * * \\
(0.0555)\end{array}$ & - \\
\hline $\begin{array}{l}\text { Lag of R\&D } \\
\text { expenditure }\end{array}$ & - & - & - & - & - & $\begin{array}{l}0.4503^{* * *} \\
(0.1453)\end{array}$ \\
\hline Year effects & Yes & Yes & Yes & Yes & Yes & Yes \\
\hline $\begin{array}{l}\text { Number of } \\
\text { observations }\end{array}$ & 929 & 1057 & 761 & 837 & 990 & 445 \\
\hline
\end{tabular}

Note: Robust standard errors are in parentheses. ${ }^{* * *} p=0.01,{ }^{* *} p=0.05,{ }^{*} p=0.10$.

Source: Authors' own computations 
These results suggest that there is no impact of IPP charges on high-tech exports, FDI outflow or unemployment, in static or dynamic sense. In the case of GDP and GDP growth, there seems to be a small positive effect of current level of IPP charges, but a negative effect of IPP charges in the previous year. In the case of R\&D expenditure, the effect of current level of IPP charges is statistically insignificant (but negative), whereas the effect of lagged IPP charges is positive. To provide an answer to the question whether the effects of current and lagged IPP charges may offset each other, we repeated our regression for GDP, GDP growth and R\&D expenditure once more, this time including both current and lagged IPP charges. The results are presented in Table 4.

Table 4 | Impact on GDP and R\&D

\begin{tabular}{|l|c|c|c|}
\hline & GDP growth & GDP (log) & R\&D expenditure \\
\hline IPP charges (log) & $\begin{array}{c}0.0026 \\
(0.0027)\end{array}$ & $\begin{array}{c}0.0038^{* *} \\
(0.0018)\end{array}$ & $\begin{array}{c}-0.0064 \\
(0.0094)\end{array}$ \\
\hline \multirow{2}{*}{ Lag of IPP charges (log) } & $\begin{array}{c}-0.0065^{* *} \\
(0.0027)\end{array}$ & $\begin{array}{c}-0.0019 \\
(0.0012)\end{array}$ & $\begin{array}{c}\text { (lo. } \\
\left(0.0056^{* *}\right.\end{array}$ \\
\hline \multirow{2}{*}{ Inflation } & $-0.0005^{* *}$ & $-0.0004^{* *}$ & $-0.0013^{*}$ \\
\hline \multirow{2}{*}{ Lag of GDP growth } & $(0.0002)$ & $(0.0002)$ & $(0.0007)$ \\
\hline Lag of GDP (log) & $0.2259^{* * *}$ & - & - \\
\hline Lag of R\&D expenditure & $(0.0827)$ & - & - \\
\hline Year effects & - & $0.7578^{* * *}$ & - \\
\hline Number of observations & - & $(0.0545)$ & $0.4344^{* * *}$ \\
\hline
\end{tabular}

Source: Authors' own computations

The results from this model are qualitatively similar to those presented in Tables 2 and Table 3. The advantage of this model is that is allows us to test formally whether the impact of IPP charges and lagged IPP charges offset each other (simply by testing whether the sum of the two coefficients is equal to zero). The result of our test is that we cannot reject the hypothesis of the two coefficients summing up to zero, confirming thus the offsetting of the two effects, for GDP growth and GDP. For R\&D expenditure, we can reject the hypothesis of the two coefficients summing up to zero confirming thus that the two effects do not offset each other. 


\subsection{Countries divided into income categories}

Since the impact of IPP can be very different for countries of different income level, we repeated the above presented analysis separately for four groups of countries divided according to their income level using the official World Bank classification? In the first group there are high income countries. We present results of our analysis for this group in Tables A3 and A4 in the Appendix. As compared to the results for the whole sample, there are two main differences. First, unemployment seems to be reduced with increasing IPP charges, both when considered in the current period or lagged. The impact is not strong economically, when IPP charges increase by $1 \%$, unemployment is reduced by less than 0.01 percentage points, yet, the influence is statistically significant. Second, the FDI outflow is positively influenced by current IPP charges (1\% increase of IPP charges increases FDI outflows by 0.4 percentage points) and negatively by lagged IPP charges ( $1 \%$ increase of IPP charges in previous period decreases current FDI outflows by 0.1 percentage points). Using a model with both current and lagged IPP charges, we formally tested that the positive effect outweighs the negative one. This could be explained by the benefits of IPP: the possibility of acquiring a form of IPP spurs FDI in the initial time period, but incurred costs and the acquired control over the technology (for example, a shell patent) demotivate, i.e. postpone, it in the subsequent ones.

The second and third groups are upper middle-income and lower middle-income countries. For these groups, the results presented in Tables A5-A8 in the Appendix do not differ significantly from the estimation over the whole sample (if there is any difference, it is not statistically significant or it is economically negligible).

The fourth group are low income countries, for which we present our results in Tables A9 and A10 in the Appendix. This is the only group of countries in which both current and lagged IPP charges positively impact the R\&D expenditure, even though the real economic impact is very mild. Lagged IPP charges positively impact high-tech exports from these countries ( $1 \%$ increase of IPP charges increases high-tech exports by 0.01 percentage points), so we find some evidence that IPP charges in low-income countries foster technological development in low income countries, even though very moderately.

\section{Conclusion}

Our results show that there is practically no effect of IPP on economic performance of a country. On the most aggregate level, IPP boosts very moderately current GDP and GDP growth, but at the same time, it has the opposite impact on these two indicators in the next period. The two effects, both economically very small, offset each other. In addition, even in the current time period, IPP does not seem to reduce unemployment in any way, except for a rather weak impact on high income countries.

If we focus only on technologically more advanced sectors, in which IPP should play major role, these do not seem to benefit excessively from IPP either. In high income

$7 \quad$ More details about World Bank classification by income can be found here: https://datahelpdesk. worldbank.org/knowledgebase/articles/378834-how-does-the-world-bank-classify-countries 
countries, IPP charges help to increase FDI outflow, and in low income countries, they contribute to R\&D expenditure and high-tech exports, which signals that there might be some accumulation of benefits in the long run. However, even if statistically significant, this effect is economically too small.

The above mentioned allow us to conclude that our hypothesis is proven. The presentday IPP creates a form of non-market protection which does not positively affect GDP and GDP growth. Nor it positively affected other tested real economy variables including inflation, unemployment, high-tech exports, FDI outflow or R\&D expenditure. Taking into account that IPP already generates adverse effects and important opportunity costs, the reasonable course of action seems to be weakening rather than strengthening such regulation.

\section{Appendix}

Table A1 | List of Countries

\begin{tabular}{|c|c|c|c|c|}
\hline Afghanistan & Colombia & Iceland & Mongolia & Solomon Islands \\
\hline Albania & Congo, Dem. Rep. & India & Montenegro & South Africa \\
\hline Algeria & Costa Rica & Indonesia & Morocco & Spain \\
\hline Antigua and Barbuda & Cote d'Ivoire & Iraq & Mozambique & St. Kitts and Nevis \\
\hline Australia & Croatia & Ireland & Namibia & St. Lucia \\
\hline Austria & Cyprus & Israel & Netherlands & $\begin{array}{l}\text { St. Vincent and } \\
\text { the Grenadines }\end{array}$ \\
\hline Azerbaijan & Czech Republic & Italy & New Zealand & Sudan \\
\hline Bahamas & Denmark & Jamaica & Nicaragua & Suriname \\
\hline Bangladesh & Dominica & Japan & Niger & Swaziland \\
\hline Barbados & Dominican Republic & Kazakhstan & Nigeria & Sweden \\
\hline Belarus & Ecuador & Kenya & Norway & Switzerland \\
\hline Belgium & Egypt, Arab Rep. & Korea, Rep. & Pakistan & Tajikistan \\
\hline Belize & El Salvador & Kosovo & Panama & Tanzania \\
\hline Benin & Estonia & Kyrgyz Republic & Paraguay & Thailand \\
\hline Bermuda & Ethiopia & Latvia & Peru & Timor-Leste \\
\hline Bhutan & Fiji & Lebanon & Philippines & Togo \\
\hline Bolivia & Finland & Lesotho & Poland & Tonga \\
\hline $\begin{array}{l}\text { Bosnia and } \\
\text { Herzegovina }\end{array}$ & France & Lithuania & Portugal & Tunisia \\
\hline Botswana & Georgia & Luxembourg & Romania & Turkey \\
\hline Brazil & Germany & Macao SAR, China & Russian Federation & Uganda \\
\hline Brunei Darussalam & Greece & Macedonia, FYR & Rwanda & Ukraine \\
\hline Bulgaria & Grenada & Madagascar & Samoa & United Kingdom \\
\hline Burkina Faso & Guatemala & Malawi & Sao Tome and Principe & United States \\
\hline Burundi & Guinea & Malaysia & Senegal & Uruguay \\
\hline Cabo Verde & Guinea-Bissau & Maldives & Serbia & Vanuatu \\
\hline Cambodia & Guyana & Mali & Seychelles & Venezuela \\
\hline Cameroon & Haiti & Malta & Sierra Leone & West Bank and Gaza \\
\hline Canada & Honduras & Mauritius & Singapore & Yemen, Rep. \\
\hline Chile & Hong Kong SAR, China & Mexico & Slovak Republic & Zambia \\
\hline China & Hungary & Moldova & Slovenia & \\
\hline
\end{tabular}


Table A2 | Descriptive Statistics of Used Variables

\begin{tabular}{|c|c|c|c|c|c|}
\hline Variable & $\begin{array}{c}\text { Number of } \\
\text { observations }\end{array}$ & Mean & Std. dev. & Min & Max \\
\hline IPP charges & 1,297 & $1.91 \mathrm{E}+09$ & $5.75 \mathrm{E}+09$ & 2019.072 & $4.64 \mathrm{E}+10$ \\
\hline GDP growth & 1,167 & 0.0362184 & 0.0439019 & -0.1508839 & 0.345 \\
\hline GDP & 1,297 & $6.10 \mathrm{E}+11$ & $1.84 \mathrm{E}+12$ & $5.05 \mathrm{E}+08$ & $1.66 \mathrm{E}+13$ \\
\hline High-tech exports & 1,030 & 10.28666 & 12.15036 & 0 & 87.40443 \\
\hline FDI outflow & 1,084 & 7.659935 & 52.65672 & -158.4786 & 776.4378 \\
\hline Unemployment & 1,202 & 8.765973 & 6.075979 & 0.1 & 37.6 \\
\hline R\&D expenditure & 651 & 1.070686 & 0.9944988 & 0.01283 & 4.47954 \\
\hline
\end{tabular}

Source: Authors' own computations

Table A3 | Results of Regression with Current IPP Charges for High Income Countries

\begin{tabular}{|c|c|c|c|c|c|c|}
\hline \multicolumn{7}{|c|}{ Explanatory variable } \\
\hline & $\begin{array}{c}\text { GDP } \\
\text { growth }\end{array}$ & $\begin{array}{l}\text { GDP } \\
(\log )\end{array}$ & $\begin{array}{l}\text { High-tech } \\
\text { exports }\end{array}$ & $\begin{array}{c}\text { FDI } \\
\text { outflow }\end{array}$ & $\begin{array}{l}\text { Unemploy- } \\
\text { ment }\end{array}$ & $\begin{array}{c}R \& D \\
\text { expenditure }\end{array}$ \\
\hline IPP charges (log) & $\begin{array}{c}0.0046 \\
(0.0066)\end{array}$ & $\begin{array}{l}0.0130^{* * *} \\
(0.0041)\end{array}$ & $\begin{array}{c}0.8513 \\
(0.6862)\end{array}$ & $\begin{array}{l}38.9906^{*} \\
(20.5450)\end{array}$ & $\begin{array}{c}-0.6515^{* *} \\
(0.3291)\end{array}$ & $\begin{array}{c}0.0115 \\
(0.0311)\end{array}$ \\
\hline Inflation & $\begin{array}{l}0.0001 \\
(0.0007)\end{array}$ & $\begin{array}{l}0.0008^{*} \\
(0.0005)\end{array}$ & $\begin{array}{c}0.0354 \\
(0.1198)\end{array}$ & $\begin{array}{c}0.1046 \\
(0.6643)\end{array}$ & $\begin{array}{l}-0.0871 \\
(0.0609)\end{array}$ & $\begin{array}{l}-0.0057 \\
(0.0051)\end{array}$ \\
\hline Lag of GDP growth & $\begin{array}{l}0.4009^{* * *} \\
(0.0909)\end{array}$ & - & - & - & - & $\begin{array}{l}- \\
-\end{array}$ \\
\hline Lag of GDP (log) & $\begin{array}{l}- \\
-\end{array}$ & $\begin{array}{l}0.9279^{* * *} \\
(0.0234)\end{array}$ & - & - & - & - \\
\hline $\begin{array}{l}\text { Lag of high-tech } \\
\text { exports }\end{array}$ & $\begin{array}{l}- \\
-\end{array}$ & - & $\begin{array}{l}0.7580^{* * *} \\
(0.1621)\end{array}$ & - & - & - \\
\hline Lag of FDI outflow & $\begin{array}{l}- \\
-\end{array}$ & - & - & $\begin{array}{l}-0.0336 \\
(0.0891)\end{array}$ & - & - \\
\hline $\begin{array}{l}\text { Lag of } \\
\text { unemployment }\end{array}$ & $\begin{array}{l}- \\
-\end{array}$ & $\begin{array}{l}- \\
-\end{array}$ & - & - & $\begin{array}{l}0.5684^{* * *} \\
(0.0304)\end{array}$ & - \\
\hline Lag of R\&D & - & - & - & - & - & $0.5273^{* * *}$ \\
\hline expenditure & - & - & - & - & - & $(0.1399)$ \\
\hline Year effects & Yes & Yes & Yes & Yes & Yes & Yes \\
\hline $\begin{array}{l}\text { Number } \\
\text { of observations }\end{array}$ & 302 & 349 & 293 & 324 & 321 & 251 \\
\hline
\end{tabular}

Note: Robust standard errors are in parentheses. ${ }^{* * *} p=0.01,{ }^{* *} p=0.05,{ }^{*} p=0.10$.

Source: Authors' own computations 
Table A4 | Results of Regression with Lagged IPP Charges for High-Income Countries

\begin{tabular}{|c|c|c|c|c|c|c|}
\hline \multicolumn{7}{|c|}{ Explanatory variable } \\
\hline & $\begin{array}{c}\text { GDP } \\
\text { growth }\end{array}$ & GDP (log) & $\begin{array}{l}\text { High-tech } \\
\text { exports }\end{array}$ & $\begin{array}{c}\text { FDI } \\
\text { outflow }\end{array}$ & $\begin{array}{l}\text { Unemploy- } \\
\text { ment }\end{array}$ & $\begin{array}{c}\text { R\&D } \\
\text { expenditure }\end{array}$ \\
\hline $\begin{array}{l}\text { Lag of IPP charges } \\
\text { (log) }\end{array}$ & $\begin{array}{l}-0.0135^{* *} \\
(0.0054)\end{array}$ & $\begin{array}{c}0.0037 \\
(0.0050)\end{array}$ & $\begin{array}{c}0.1496 \\
(0.8000)\end{array}$ & $\begin{array}{c}-9.7720 * * \\
(4.8864)\end{array}$ & $\begin{array}{l}-0.7170^{* * *} \\
(0.2725)\end{array}$ & $\begin{array}{c}0.0339 \\
(0.0276)\end{array}$ \\
\hline Inflation & $\begin{array}{l}-0.0005 \\
(0.0006)\end{array}$ & $\begin{array}{c}0.0003 \\
(0.0004)\end{array}$ & $\begin{array}{l}0.0411 \\
(0.1124)\end{array}$ & $\begin{array}{l}-0.0587 \\
(0.4549)\end{array}$ & $\begin{array}{l}-0.0858 \\
(0.0633)\end{array}$ & $\begin{array}{l}-0.0048 \\
(0.0047)\end{array}$ \\
\hline Lag of GDP growth & $\begin{array}{l}0.4691^{* * *} \\
(0.0681)\end{array}$ & - & $\begin{array}{l}- \\
-\end{array}$ & $\begin{array}{l}- \\
-\end{array}$ & - & - \\
\hline Lag of GDP (log) & $\begin{array}{l}- \\
-\end{array}$ & $\begin{array}{l}0.7119 * * * \\
(0.0338)\end{array}$ & - & - & $\begin{array}{l}- \\
-\end{array}$ & $\begin{array}{l}- \\
-\end{array}$ \\
\hline $\begin{array}{l}\text { Lag of high-tech } \\
\text { exports }\end{array}$ & $\begin{array}{l}- \\
-\end{array}$ & $\begin{array}{l}- \\
-\end{array}$ & $\begin{array}{l}0.8149 * * * \\
(0.1318)\end{array}$ & - & $\begin{array}{l}- \\
-\end{array}$ & - \\
\hline Lag of FDI outflow & - & $\begin{array}{l}- \\
-\end{array}$ & $\begin{array}{l}- \\
-\end{array}$ & $\begin{array}{c}0.1051 \\
(0.0930)\end{array}$ & - & - \\
\hline $\begin{array}{l}\text { Lag of } \\
\text { unemployment }\end{array}$ & - & - & - & $\begin{array}{l}- \\
-\end{array}$ & $\begin{array}{l}0.5216^{* * *} \\
(0.0333)\end{array}$ & - \\
\hline $\begin{array}{l}\text { Lag of R\&D } \\
\text { expenditure }\end{array}$ & - & $\begin{array}{l}- \\
-\end{array}$ & $\begin{array}{l}- \\
-\end{array}$ & - & - & $\begin{array}{l}0.5136^{* * *} \\
(0.1416)\end{array}$ \\
\hline Year effects & Yes & Yes & Yes & Yes & Yes & Yes \\
\hline $\begin{array}{l}\text { Number } \\
\text { of observations }\end{array}$ & 314 & 360 & 295 & 326 & 331 & 252 \\
\hline
\end{tabular}

Note: Robust standard errors are in parentheses. ${ }^{* *} p=0.01,{ }^{* *} p=0.05,{ }^{*} p=0.10$.

Source: Authors' own computations

Table A5 | Results of Regression with Current IPP Charges for Upper Middle-Income Countries

\begin{tabular}{|c|c|c|c|c|c|c|}
\hline \multicolumn{7}{|c|}{ Explanatory variable } \\
\hline & $\begin{array}{c}\text { GDP } \\
\text { growth }\end{array}$ & GDP (log) & $\begin{array}{l}\text { High-tech } \\
\text { exports }\end{array}$ & $\begin{array}{c}\text { FDI } \\
\text { outflow }\end{array}$ & $\begin{array}{c}\text { Unemploy- } \\
\text { ment }\end{array}$ & $\begin{array}{c}R \& D \\
\text { expenditure }\end{array}$ \\
\hline \multirow{2}{*}{ IPP charges (log) } & -0.0083 & -0.0067 & 0.4226 & 1.4175 & 0.5628 & -0.0336 \\
\hline & $(0.0067)$ & $(0.0047)$ & $(0.4466)$ & (3.1362) & $(0.5321)$ & $(0.0250)$ \\
\hline \multirow{2}{*}{ Inflation } & $-0.0009 * *$ & $-0.0006^{* *}$ & -0.0299 & -0.0858 & 0.0080 & -0.0001 \\
\hline & $(0.0004)$ & $(0.0002)$ & $(0.0203)$ & $(0.1376)$ & $(0.0118)$ & $(0.0006)$ \\
\hline \multirow{2}{*}{$\begin{array}{l}\text { Lag of GDP } \\
\text { growth }\end{array}$} & $0.2733^{* *}$ & - & - & - & - & - \\
\hline & $(0.1246)$ & - & - & - & - & - \\
\hline \multirow{2}{*}{ Lag of GDP (log) } & - & $0.8185^{* * *}$ & - & - & - & - \\
\hline & - & $(0.0998)$ & - & - & - & - \\
\hline
\end{tabular}

Continuation on next page. 
Table A5 (continuation)

\begin{tabular}{|c|c|c|c|c|c|c|}
\hline $\begin{array}{l}\text { Lag of high-tech } \\
\text { exports }\end{array}$ & - & - & $\begin{array}{c}0.0871 \\
(0.0835)\end{array}$ & - & - & - \\
\hline $\begin{array}{l}\text { Lag of FDI } \\
\text { outflow }\end{array}$ & - & - & - & $\begin{array}{c}-0.2531^{* * *} \\
(0.0215)\end{array}$ & - & - \\
\hline $\begin{array}{l}\text { Lag of unem- } \\
\text { ployment }\end{array}$ & - & - & - & - & $\begin{array}{l}0.5123^{* * *} \\
(0.0488)\end{array}$ & - \\
\hline $\begin{array}{l}\text { Lag of } R \& D \\
\text { expenditure }\end{array}$ & - & - & - & - & - & $\begin{array}{c}0.3020 \\
(0.2048) \\
\end{array}$ \\
\hline Year effects & Yes & Yes & Yes & Yes & Yes & Yes \\
\hline $\begin{array}{l}\text { Number } \\
\text { of observations }\end{array}$ & 264 & 301 & 232 & 244 & 273 & 109 \\
\hline
\end{tabular}

Note: Robust standard errors are in parentheses. ${ }^{* *} p=0.01,{ }^{* *} p=0.05,{ }^{*} p=0.10$.

Source: Authors' own computations

Table A6 | Results of Regression with Lagged IPP Charges for Upper Middle-Income Countries

\begin{tabular}{|c|c|c|c|c|c|c|}
\hline \multicolumn{7}{|c|}{ Explanatory variable } \\
\hline & $\begin{array}{c}\text { GDP } \\
\text { growth }\end{array}$ & $\begin{array}{l}\text { GDP } \\
(\log )\end{array}$ & $\begin{array}{l}\text { High-tech } \\
\text { exports }\end{array}$ & $\begin{array}{c}\text { FDI } \\
\text { outflow }\end{array}$ & $\begin{array}{c}\text { Unemploy- } \\
\text { ment }\end{array}$ & $\begin{array}{c}R \& D \\
\text { expenditure }\end{array}$ \\
\hline $\begin{array}{l}\text { Lag of IPP } \\
\text { charges (log) }\end{array}$ & $\begin{array}{c}0.0000 \\
(0.0067)\end{array}$ & $\begin{array}{l}-0.0037 \\
(0.0027)\end{array}$ & $\begin{array}{c}0.6967 \\
(0.8824)\end{array}$ & $\begin{array}{l}-1.1909 \\
(2.5646)\end{array}$ & $\begin{array}{l}-0.3348 \\
(0.4061)\end{array}$ & $\begin{array}{c}0.0130^{*} \\
(0.0068)\end{array}$ \\
\hline Inflation & $\begin{array}{c}-0.0008^{*} \\
(0.0004)\end{array}$ & $\begin{array}{c}-0.0005^{* *} \\
(0.0002)\end{array}$ & $\begin{array}{l}-0.0286 \\
(0.0233)\end{array}$ & $\begin{array}{l}-0.0866 \\
(0.2142)\end{array}$ & $\begin{array}{l}0.0038 \\
(0.0111)\end{array}$ & $\begin{array}{l}-0.0005 \\
(0.0005)\end{array}$ \\
\hline $\begin{array}{l}\text { Lag of GDP } \\
\text { growth }\end{array}$ & $\begin{array}{l}0.2954^{* *} \\
(0.1378)\end{array}$ & - & - & - & $\begin{array}{l}- \\
-\end{array}$ & - \\
\hline Lag of GDP (log) & $\begin{array}{l}- \\
-\end{array}$ & $\begin{array}{l}0.7980^{* * *} \\
(0.0329)\end{array}$ & - & $\begin{array}{l}- \\
-\end{array}$ & - & - \\
\hline $\begin{array}{l}\text { Lag of high-tech } \\
\text { exports }\end{array}$ & - & - & $\begin{array}{c}0.0872 \\
(0.0837)\end{array}$ & - & - & - \\
\hline $\begin{array}{l}\text { Lag of FDI } \\
\text { outflow }\end{array}$ & - & - & - & $\begin{array}{c}-0.2539 * * * \\
(0.0203)\end{array}$ & - & - \\
\hline $\begin{array}{l}\text { Lag of } \\
\text { unemployment }\end{array}$ & - & - & - & - & $\begin{array}{l}0.5409 * * * \\
(0.0500)\end{array}$ & - \\
\hline $\begin{array}{l}\text { Lag of } R \& D \\
\text { expenditure }\end{array}$ & - & - & - & - & - & $\begin{array}{l}0.3566^{*} \\
(0.1993)\end{array}$ \\
\hline Year effects & Yes & Yes & Yes & Yes & Yes & Yes \\
\hline $\begin{array}{l}\text { Number } \\
\text { of observations }\end{array}$ & 278 & 313 & 231 & 243 & 281 & 109 \\
\hline
\end{tabular}

Note: Robust standard errors are in parentheses. ${ }^{* * *} p=0.01,{ }^{* *} p=0.05,{ }^{*} p=0.10$.

Source: Authors' own computations 
Table A7 | Results of Regression with Current IPP Charges for Lower Middle-Income Countries

\begin{tabular}{|l|c|c|c|c|c|c|}
\hline \multicolumn{1}{|c|}{} & $\begin{array}{c}\text { GDP } \\
\text { growth }\end{array}$ & $\begin{array}{c}\text { GDP } \\
\text { (log) }\end{array}$ & $\begin{array}{c}\text { High-tech } \\
\text { exports }\end{array}$ & $\begin{array}{c}\text { FDI } \\
\text { outflow }\end{array}$ & $\begin{array}{c}\text { Unemploy- } \\
\text { ment }\end{array}$ & $\begin{array}{c}\text { R\&D } \\
\text { expenditure }\end{array}$ \\
\hline IPP charges (log) & $\begin{array}{c}0.0037 \\
(0.0025)\end{array}$ & $\begin{array}{c}0.0054^{* * *} \\
(0.0021)\end{array}$ & $\begin{array}{c}-0.0182 \\
(1.3026)\end{array}$ & $\begin{array}{c}-0.0852 \\
(0.1475)\end{array}$ & $\begin{array}{c}0.0237 \\
(0.0379)\end{array}$ & $\begin{array}{c}-0.0195^{* *} \\
(0.0080)\end{array}$ \\
\hline Inflation & -0.0000 & 0.0000 & 0.0139 & -0.0022 & -0.0033 & 0.0006 \\
& $(0.0001)$ & $(0.0001)$ & $(0.0261)$ & $(0.0058)$ & $(0.0049)$ & $(0.0010)$ \\
\hline $\begin{array}{l}\text { Lag of GDP } \\
\text { growth }\end{array}$ & $\begin{array}{l}0.0227 \\
(0.0698)\end{array}$ & - & - & - & - & - \\
\hline Lag of GDP (log) & - & - & - & - & - & - \\
\hline Lag of high-tech \\
exports
\end{tabular}

Note: Robust standard errors are in parentheses. ${ }^{* * *} p=0.01,{ }^{* *} p=0.05,{ }^{*} p=0.10$.

Source: Authors' own computations

Table A8 | Results of Regression with Lagged IPP Charges for Lower Middle-Income Countries

\begin{tabular}{|l|c|c|c|c|c|c|}
\hline \multicolumn{7}{|c|}{ Explanatory variable } \\
\hline & $\begin{array}{c}\text { GDP } \\
\text { growth }\end{array}$ & $\begin{array}{c}\text { GDP } \\
(\mathbf{l o g})\end{array}$ & $\begin{array}{c}\text { High-tech } \\
\text { exports }\end{array}$ & $\begin{array}{c}\text { FDI } \\
\text { outflow }\end{array}$ & $\begin{array}{c}\text { Unemploy- } \\
\text { ment }\end{array}$ & $\begin{array}{c}\text { R\&D } \\
\text { expenditure }\end{array}$ \\
\hline \multirow{2}{*}{$\begin{array}{l}\text { Lag of IPP charges } \\
\text { (log) }\end{array}$} & $-0.0068^{* * *}$ & -0.0025 & -1.3076 & -0.0810 & 0.1527 & -0.0052 \\
& $(0.0017)$ & $(0.0021)$ & $(1.4633)$ & $(0.0926)$ & $(0.0968)$ & $(0.0077)$ \\
\hline \multirow{2}{*}{ Inflation } & $-0.0068^{* * *}$ & -0.0025 & -1.3076 & -0.0810 & 0.1527 & -0.0052 \\
& $(0.0002)$ & $(0.0002)$ & $(0.0254)$ & $(0.0049)$ & $(0.0036)$ & $(0.0010)$ \\
\hline \multirow{2}{*}{$\begin{array}{l}\text { Lag of GDP } \\
\text { growth }\end{array}$} & 0.0585 & - & - & - & - & - \\
\hline \multirow{2}{*}{ Lag of GDP $(\mathbf{l o g})$} & - & - & - & - & - & - \\
\hline
\end{tabular}

Continuation on next page. 
Table A8 (continuation)

\begin{tabular}{|c|c|c|c|c|c|c|}
\hline $\begin{array}{l}\text { Lag of high-tech } \\
\text { exports }\end{array}$ & - & - & $\begin{array}{l}0.3644 \\
(0.2479)\end{array}$ & $\begin{array}{l}- \\
-\end{array}$ & - & - \\
\hline $\begin{array}{l}\text { Lag of FDI } \\
\text { outflow }\end{array}$ & - & $\begin{array}{l}- \\
-\end{array}$ & - & $\begin{array}{c}0.0140 \\
(0.0579)\end{array}$ & $\begin{array}{l}- \\
-\end{array}$ & $\begin{array}{l}- \\
-\end{array}$ \\
\hline $\begin{array}{l}\text { Lag of } \\
\text { unemployment }\end{array}$ & - & $\begin{array}{l}- \\
-\end{array}$ & $\begin{array}{l}- \\
-\end{array}$ & $\begin{array}{l}- \\
-\end{array}$ & $\begin{array}{l}0.3141^{* * *} \\
(0.0638)\end{array}$ & $\begin{array}{l}- \\
-\end{array}$ \\
\hline $\begin{array}{l}\text { Lag of } R \& D \\
\text { expenditure }\end{array}$ & $\begin{array}{l}- \\
-\end{array}$ & $\begin{array}{l}- \\
-\end{array}$ & $\begin{array}{l}- \\
-\end{array}$ & $\begin{array}{l}- \\
-\end{array}$ & - & $\begin{array}{l}0.6384^{* * *} \\
(0.1380)\end{array}$ \\
\hline Year effects & Yes & Yes & Yes & Yes & Yes & Yes \\
\hline $\begin{array}{l}\text { Number } \\
\text { of observations }\end{array}$ & 216 & 245 & 153 & 187 & 231 & 58 \\
\hline
\end{tabular}

Note: Robust standard errors are in parentheses. ${ }^{* *} p=0.01,{ }^{* *} p=0.05,{ }^{*} p=0.10$.

Source: Authors' own computations

Table A9 | Results of Regression with Current IPP Charges for Low-Income Countries

\begin{tabular}{|c|c|c|c|c|c|c|}
\hline \multicolumn{7}{|c|}{ Explanatory variable } \\
\hline & $\begin{array}{c}\text { GDP } \\
\text { growth }\end{array}$ & $\begin{array}{l}\text { GDP } \\
(\log )\end{array}$ & $\begin{array}{l}\text { High-tech } \\
\text { exports }\end{array}$ & $\begin{array}{l}\text { FDI } \\
\text { outflow }\end{array}$ & $\begin{array}{l}\text { Unemploy- } \\
\text { ment }\end{array}$ & $\begin{array}{c}R \& D \\
\text { expenditure }\end{array}$ \\
\hline \multirow{2}{*}{ IPP charges (log) } & 0.0064 & 0.0041 & 0.7419 & -0.5757 & -0.0119 & $0.0245^{*}$ \\
\hline & $(0.0041)$ & $(0.0033)$ & $(0.7997)$ & $(0.3813)$ & $(0.0419)$ & $(0.0137)$ \\
\hline \multirow{2}{*}{ Inflation } & $-0.0016^{* *}$ & $-0.0010^{*}$ & $-0.2060^{* *}$ & 0.0250 & $0.0096^{* *}$ & $0.0019^{* * *}$ \\
\hline & $(0.0007)$ & $(0.0005)$ & $(0.0880)$ & $(0.0297)$ & $(0.0042)$ & $(0.0006)$ \\
\hline \multirow{2}{*}{$\begin{array}{l}\text { Lag of GDP } \\
\text { growth }\end{array}$} & $-0.3445^{*}$ & - & - & - & - & - \\
\hline & $(0.1917)$ & - & - & - & - & - \\
\hline \multirow{2}{*}{ Lag of GDP (log) } & - & $0.9196^{* * *}$ & - & - & - & - \\
\hline & - & $(0.0513)$ & - & - & - & - \\
\hline \multirow{2}{*}{$\begin{array}{l}\text { Lag of high-tech } \\
\text { exports }\end{array}$} & - & - & 0.0985 & - & - & - \\
\hline & - & - & $(0.0746)$ & - & - & - \\
\hline \multirow{2}{*}{$\begin{array}{l}\text { Lag of FDI } \\
\text { outflow }\end{array}$} & - & - & - & 0.1441 & - & - \\
\hline & - & - & - & $(0.0997)$ & - & - \\
\hline \multirow{2}{*}{$\begin{array}{l}\text { Lag of } \\
\text { unemployment }\end{array}$} & - & - & - & - & $-0.2567^{* * *}$ & - \\
\hline & - & - & - & - & $(0.0719)$ & - \\
\hline \multirow{2}{*}{$\begin{array}{l}\text { Lag of R\&D } \\
\text { expenditure }\end{array}$} & - & - & - & - & - & $0.5147^{* * *}$ \\
\hline & - & - & - & - & - & $(0.1716)$ \\
\hline Year effects & Yes & Yes & Yes & Yes & Yes & Yes \\
\hline $\begin{array}{l}\text { Number } \\
\text { of observations }\end{array}$ & 82 & 97 & 63 & 55 & 97 & 10 \\
\hline
\end{tabular}

Note: Robust standard errors are in parentheses. ${ }^{* *} p=0.01,{ }^{* *} p=0.05,{ }^{*} p=0.10$.

Source: Authors' own computations 
Table A10 | Results of Regression with Lagged IPP Charges for Low-Income Countries

\begin{tabular}{|c|c|c|c|c|c|c|}
\hline \multicolumn{7}{|c|}{ Explanatory variable } \\
\hline & $\begin{array}{c}\text { GDP } \\
\text { growth }\end{array}$ & $\begin{array}{l}\text { GDP } \\
(\log )\end{array}$ & $\begin{array}{l}\text { High-tech } \\
\text { exports }\end{array}$ & $\begin{array}{l}\text { FDI } \\
\text { outflow }\end{array}$ & $\begin{array}{l}\text { Unemploy- } \\
\text { ment }\end{array}$ & $\begin{array}{c}\text { R\&D } \\
\text { expenditure }\end{array}$ \\
\hline \multirow{2}{*}{$\begin{array}{l}\text { Lag of IPP charges } \\
\text { (log) }\end{array}$} & $-0.0073^{* * *}$ & -0.0021 & $0.9887^{*}$ & 0.1731 & -0.0333 & $0.0280 * * *$ \\
\hline & $(0.0026)$ & $(0.0026)$ & $(0.5798)$ & $(0.6769)$ & $(0.0351)$ & $(0.0006)$ \\
\hline \multirow{2}{*}{ Inflation } & $-0.0011^{* * *}$ & $-0.0009^{*}$ & $-0.2234^{* * *}$ & 0.1266 & $0.0093^{* * *}$ & $0.0025^{* * *}$ \\
\hline & $(0.0004)$ & $(0.0004)$ & $(0.0788)$ & $(0.0803)$ & $(0.0034)$ & $(0.0005)$ \\
\hline \multirow{2}{*}{$\begin{array}{l}\text { Lag of GDP } \\
\text { growth }\end{array}$} & $-0.2059 * *$ & - & - & - & - & - \\
\hline & $(0.0907)$ & - & - & - & - & - \\
\hline \multirow{2}{*}{ Lag of GDP (log) } & - & $0.8111^{* * *}$ & - & - & - & - \\
\hline & - & $(0.0523)$ & - & - & - & - \\
\hline \multirow{2}{*}{$\begin{array}{l}\text { Lag of high-tech } \\
\text { exports }\end{array}$} & - & - & 0.0486 & - & - & - \\
\hline & - & - & $(0.0730)$ & - & - & - \\
\hline \multirow{2}{*}{ Lag of FDI outflow } & - & - & - & 0.4751 & - & - \\
\hline & - & - & - & $(0.4384)$ & - & - \\
\hline \multirow{2}{*}{$\begin{array}{l}\text { Lag of } \\
\text { unemployment }\end{array}$} & - & - & - & - & $-0.1963^{* *}$ & - \\
\hline & - & - & - & - & $(0.0911)$ & - \\
\hline \multirow{2}{*}{$\begin{array}{l}\text { Lag of } R \& D \\
\text { expenditure }\end{array}$} & - & - & - & - & - & $0.4044^{* * *}$ \\
\hline & - & - & - & - & - & $(0.0546)$ \\
\hline Year effects & Yes & Yes & Yes & Yes & Yes & Yes \\
\hline $\begin{array}{l}\text { Number } \\
\text { of observations }\end{array}$ & 97 & 112 & 68 & 58 & 112 & 10 \\
\hline
\end{tabular}

Note: Robust standard errors are in parentheses. ${ }^{* * *} p=0.01,{ }^{* *} p=0.05,{ }^{*} p=0.10$.

Source: Authors' own computations

\section{References}

Arellano, M., Bond, S. (1991). Some Tests of Specification for Panel Data: Monte Carlo Evidence and an Application to Employment Equations. The Review of Economic Studies, 58(2), 277-297, https://doi.org/10.2307/2297968

Boldrin, M., Levine, D. (2008). Against Intellectual Monopoly. Cambridge Books. Cambridge: University Press, Cambridge, England. ISBN: 9780521879286.

Bolotov, I., Evan, T. (2014). The Weak Relation between Foreign Direct Investment and Corruption: A Theoretical and Econometric Study. Prague Economic Papers, 23(4), 474-492, https://doi.org/10.18267/j.pep.494

Deardorff, A. V. (1992). Welfare Effects of Global Patent Protection. Economica, 59(233), 35-51, https://doi.org/10.2307/2555064

Dunning, J. H. (1988). The Eclectic Paradigm of International Production: A Restatement and Some Possible Extensions. Journal of International Business Studies, 19(1), 1-31, https://doi.org/10.1057/palgrave.jibs.8490372 
Evan, T. (2010). Some Issues of Political Economics of Multinational Corporations. Acta Oeconomica Pragensia, https://doi.org/10.18267/j.aop.311

Falvey, R., Foster, N., Greenaway D. (2006). Intellectual Property Rights and Economic Growth. Review of Development Economics, 10 (4), 700-719.

Horii, R., Iwaisako, T. (2007). Economic Growth with Imperfect Protection of Intellectual Property Rights. Journal of Economics, 90(1), 45-85, https://doi.org/10.1007/s00712-006-0222-6

Iwaisako, T., Tanaka, H., Futagami, K. (2011). A Welfare Analysis of Global Patent Protection in a Model with Endogenous Innovation and Foreign Direct Investment. European Economic Review, 55(8), 1137-1151, https://doi.org/10.1016/j.euroecorev.2011.05.001

Kanwar, S., Evenson, R. (2003). Does Intellectual Property Protection Spur Technological Change? Oxford Economic Papers, 55(2), 235-264, https://doi.org/10.1093/oep/55.2.235

Kydland, F. E, Prescott, E. C. (1982). Time to Build and Aggregate Fluctuations. Econometrica, 50(6), 1345-1370, https://doi.org/10.2307/1913386

Lee, J. Y., Mansfield, E. (1996). Intellectual Property Protection and U.S. Foreign Direct Investment. Review of Economics and Statistics, 78(2), 181-186.

Long, J. B., Plosser, C. I. (1983). Real Business Cycles. Journal of Political Economy, 91(1), 39-69, https://doi.org/10.1086/261128

Michel, P., Nyssen, J. (1998). On Knowledge Diffusion, Patents Lifetime and Innovation Based Endogenous Growth. Annalesd' Economieet de Statistique, ENSAE, 49/50, 77-103, https://doi.org/10.2307/20076111

MOFA (2011). Text of the ACTA treaty, Ministry of Foreign Affairs of Japan.

Okun, A. M. (1962). Potential GNP: Its Measurement and Significance. Reprinted as Cowles Foundation Paper 190.

Pakes, A., Griliches, Z. (1984). Patents and R\&D at the Firm Level: A First Look, in Griliches Z., ed. (1984). $R \& D$, Patents, and Productivity. Chicago: University of Chicago Press and NBER.

Samuelson, P. A. (1948). Economics: An Introductory Analysis. New York: McGraw-Hill. 622 p.

Samuelson, P. A., Nordhaus, W. (2009). Economics. 19. ed. New York: McGraw-Hill. 744 p. ISBN 978-0073511290.

Sattar, A., Mahmood, T. (2011). Intellectual Property Rights and Economic Growth: Evidences from High, Middle and Low Income Countries. Pakistan Economic and Social Review, 49(2), 163-186.

Sollow, R. M. (1956). A Contribution to the Theory of Economic Growth. The Quarterly Journal of Economics, 70(1), 65-94, https://doi.org/10.2307/1884513

Swan, T. W. (1956). Economic Growth and Capital Accumulation. The Economic Record, 32(2), 334-361, https://doi.org/10.1111/j.1475-4932.1956.tb00434.x

Thompson, M.A., Rushing, F. W. (1996). An Empirical Analysis of the Impact of Patent Protection on Economic Growth. Journal of Economic Development, 21(2), 61-77.

WIPO (2013). Intellectual Property Handbook: Policy, Law and Use. World Intellectual Property Organization. 